\title{
DUE TO LEGAL POSITION AND LEGAL SURROGACY AGREEMENT AS AN INNOMINAAT AGREEMENT IN THE PERPECTIVE OF CIVIL LAW, ISLAMIC LAW AND NATIONAL LAW
}

\author{
Peni Rinda \\ Sultan Agung Islamic University \\ penirinda00@gmail.com
}

\begin{abstract}
Technological developments in medicine have provided an outlet for community issues with the discovery of a new method of artificial insemination is known as in vitro fertilitization (IVF). For couples who want to have children but due to medical reasons can not obtain offspring naturally, with IVF method can obtain offspring / children. But in its development appears IVF lease term or the surrogate mother's womb, the sperm and ovum from a legitimate married another woman entered in the womb. Therefore the aim of this study to determine the legal position of surrogacy agreement as an innominaat agreement in the perspective of civil law, Islamic law national law,

This research used normative juridical approach, descriptive analytical research specification, method of data collection is done with a literature study on legal materials, both primary legal materials, as well as secondary materials, then analyzed by qualitative descriptive.

The results showed that a good legal position surrogacy agreement according to the Civil Law, Islamic law and national law is as the agreement is not named (innominaat) and surrogacy agreement is not allowed or unlawful. While the legal consequences of surrogacy agreements either under Civil Law, Islamic law, and national law relating to the status of children, descent problems, inheritance and other rights. The legal status of children under civil law can be a legitimate child of the surrogate mother, it could be a child outside of mating recognized, while according to Islamic law status of the child as a child of the uterus rental yields laqith, while according to national law, the legal status of the child as a foster child. This inheritance rights issue depends the legal status of the child, there is nothing not inherit (civil relationship with his mother).
\end{abstract}

Keywords: Position and Effects, surrogacy agreement, three legal systems (civil law, Islamic law and national law)

\section{A. INTRODUCTION}

\section{Background}

The purpose of marriage as embodied in Act No. 1 of 1974 on Marriage is a family (household) who are happy and everlasting based on God. Observing the purpose of marriage is evident that the aim to form a happy family in the time period is not limited and is valid for life, so that the necessary maturity and soul to be able to mate in order to realize the goal of marriage is good without an end in divorce and got a good offspring and healthy. 
Establishment of a happy family was closely connected with the descent, where the maintenance and education of children the rights and duties of parents, so that the purpose of the legislation is the happiness of marriage by the husband and wife, to obtain offspring and uphold the religious, the family unit is parental. ${ }^{1}$ Meanwhile, according to Islamic law is the purpose of marriage according to God's command to obtain a legitimate offspring, to set up housekeeping peaceful and orderly. ${ }^{2}$ In Islamic law, including a descendant of religious purpose (maqashid ash-shari'a). So in order to keep this descent or descendant of Islam demands marriage as a legitimate way to preserve the purity of descent.

In reality not every family (husband and wife) is able to have a child/descendant own. This reality becomes a problem in the family or community, so as to give a solution to this problem is known appointment of a child (adoption) that is someone else's child as her own. But there are also couples who want children of their own couple seeds despite the health problems to be able to conceive naturally. Desire couples who are not able to give birth naturally this has been answered by the development of medical technology is by IVF.

1 K. Wantjik Saleh, 1976, Hukum Perkawinan Indonesia, Edition. IV, Galia Indonesia, Jakarta, p. 15

2 Hilman Hadikusuma, 1990, Hukum Perkawinan Indonesia menurut Perundangan, Hukum Adat, Hukum Agama, Mandar Maju, p. 21
Tube baby is a baby that is generated instead of intercourse, but by taking sperm (husband) and ovum (wife), and then inserted into a tool for several days through a process and phase of conception for further inserted into the wife's womb till give birth. ${ }^{3}$ IVF is abroad are well known and has been practiced in Indonesia.

With in vitro fertilization allows couples are unable to have children by natural means for health factors can have a child of the couple seed. Efforts pregnancy outside of this natural way in Indonesian law has been regulated in Act No. 36 Of 2009 on Health. In Article 127 of Act No. 36 of 2009 reads: "The efforts of a pregnancy outside the natural way can only be done by married couples valid with the following conditions: a). the result of fertilization of the ovum and the sperm of husband and wife is concerned to implant in the wife's womb from which the ovum originated, b). carried out by health workers who have the expertise and authority to it, c). in particular health care facility.

Problems arise in the community what if it turns out the wife's womb is not medically sound, while the married couple want to have offspring of their own seeds. This can be overcome with the rental of the uterus, the sperm and ovum from a legitimate marital implanted into the surrogate

3 Husni Thamrin, 2014, Aspek Hukum Bayi Tabung dan Sewa Rahim (Perspektif Hukum Perdata dan Hukum Islam), Aswaja Presindo, Yogyakarta, p. vvi. 
mother's womb (others), known as surrogate mother (the surrogate mother). Based on the reality of the above, the authors want to conduct research on "Legal Status and Effects surrogacy agreement as Innomenaat Agreement in the Perspective of Civil Law, Islamic Law and National Law"

\section{Formulation of the problem}

Based on the description of the above background, this research is to formulate the problem as follows:

1). How can the legal position as a surrogacy agreement innominaat agreement in the perspective of civil law, Islamic law, and national law?

2). Any legal consequences arising in surrogacy agreements from the perspective of civil law, Islamic law and national law?

\section{Research methods}

a. Method approach

The study was based on a normative legal research. Normative research is intended to examine various formal review of legal regulations that law and literature contains theoretical concept. The approach used approach to law (statute approach) approach to legislation is done by examining the laws and regulations relating to the legal issues are being addressed. ${ }^{4}$

b. Legal Material Type

The type of material used in the study of law are the primary legal materials and

4 Ibid, p. 93. secondary law. Primary legal materials in this study will be assessed on the legislation relating to surrogacy agreement of the three legal systems. While the secondary law will be studied from textbooks, scientific journals and Internet news regarding surrogacy agreement.

c. Legal Materials Collection Techniques

In this normative legal study conducted by the literature on legal materials, both primary legal materials, secondary law, as well as tertiary law material or non material law. ${ }^{5}$ The collection of legal materials is done by collecting, reading, and via the Internet.

d. Data analysis method

Secondary data and primary data obtained in this study will be analyzed by descriptive qualitative that is data arranged in a systematic as the arrangement of facts to build arguments surrogacy agreement is necessary or not is set in the positive law in Indonesia.

\section{B. DISCUSSION}

1. The legal status of surrogacy agreements as the Innominaat agreement in the Perspective of Civil Law, Islamic Law and National Law.

\section{a. The legal status of surrogacy agreements as}

5 Mukti Fajar dan Yulianto Ahmad, 2007, Dualisme Penelitian Hukum, Pensil Komunika, Yogyakarta, p. 113 
the Innominaat agreement in the Civil Law Perspective.

Assessing the surrogacy agreement, it is not stipulated in the Penal Code, so that the position surrogacy agreement is included in the agreement is not named (agreement innominaat), why is that?. This is because the surrogacy agreement is not in agreement faction named as contained in the Civil Code. The question is whether people are allowed to make agreements beyond those specified in the Civil Code?. To answer that, should explore the principles or theory - the theoretical basis of the Civil Code.

In the third book in particular the Civil Code which regulates the legal commitment, embrace open systems, which means people may enter into agreements beyond that specified in the Civil Code. In addition, in the law of treaties known as the principle of freedom of contract, which means people are free to hold any treaty origin is not contrary to law, public order and decency. Thus the agreements that arise, grow and develop in society as based on two provisions that open systems and the principle of freedom of contract. Likewise, surrogacy agreements, including agreements that arise in the practice of these two conditions is the existence of an open system and the principles of freedom berkotrak. Agreements arising,

Surrogacy agreement are included in the agreement are not named or agreement is the emergence innominaat for their IVF (in vitro fertilization). Background The emergence of the IVF program due to provide solutions for couples who can not give birth naturally, but it is also the development of science and technology in the world of health (medical). Tube baby is a baby produced instead of intercourse, but by taking sperm from a male -laki (husband) and egg/ovum of a woman (wife), which is then inserted into a device (tube) for a few days through a and the process of fertilization to the next phase incorporated into the wife's womb until delivery. ${ }^{6}$ Assessing understanding of IVF mentioned above, there are three elements that need to be underlined that the first sperm and ovum of couples who tied the rope marriage, both fertilization of the egg/ovum by sperm cells in the tube, the three developing fetus transferred to a woman's womb (wife). It is the understanding of the origin of IVF, as stipulated in Article 127 of Act No. 36 Of 2009 on Health.

Starting from an understanding of IVF as stipulated in Article 127 of Act 
No. 36 of 2009 has experienced growth/expansion, the emergence of the idea of a surrogate mother or the surrogate mother. This arises because to solve existing problems in society, namely what if the wife's uterus disorders/damage, or wife since birth has no uterus, possibly also (in modern countries) wife does not want to contain because he wanted to maintain her figure. That phenomenon gave rise to the alternative of IVF where the fetus develops in the tube that has been inserted into the uterus of others, not in his wife's womb. Thus the IVF program is a clear positive impact for married couples who can not have children naturally, Observing the development of IVF surrogate mother that gave rise to the idea of this course will arise womb rental in exchange for some money, so there is an underlying economic motive. Would this be a negative impact on the development of IVF, depending from which angle the discussion, because in the Indian state's lease uterus become so common that do Indian women due to economic factors.

Surrogate mother or the surrogate mother this involves a third party that the other woman other than the wife of a married couple who have a baby. who willingly surrogate to bear their child. This phenomenon raises a new contract that arise in the community by the name of surrogacy contracts or lease contracts the uterus which in English is called surrogacy contract. The definition of surrogacy contracts awarded by Salim? :

"Any contract or agreement made between parents buyer with the mother surrogate, where the mother surrogate will conceive, give birth and hand over the child to the parents of the buyer, while the parents of the buyer is obliged to bear the costs incurred during pregnancy and childbirth, as well as rights receive babies born to surrogate mothers, according to the time period agreed between the two ".

Observing that there is an element of the definition of subject and object, namely:

The subject of surrogacy contract is: a). women already married to another party, b). women and men who live together without marriage, c). Sex Couple /same sex. Object surrogacy contract: a). pregnancy, b). birth, c). handed children born to parents buyer (biological parents).

In contract surrogacy, which can be a parent buyer is

7 Salim dan Erlies Septiana N, 2014, Perkembangan Hukum Kontrak Innomenaat di Indonesia, Edition II, Sinar Grafika, Jakarta, p. 8 
a married couple who legitimately married or an unmarried woman, while the parents of a surrogate (surrogate mothers) are a married couple who legitimately married, a woman who is not married or a grandmother. The object of the contract consists of a surrogacy pregnancy, childbirth and handed the baby to the parents of the buyer.

As in an agreement/contract in the Civil Code, the legal act known delivery (levering), then the surrogacy contract is delivery of the baby carried between a surrogate mother and the parents buyer in a real submission (real) and legally. Real or real submission is done by a surrogate mother to the parents of the buyer to submit a baby from a surrogate mother's hands into the hands of the parents of the buyer, while the juridical handover is done legally is by way of adoption through the courts.

Once it is known what surrogacy contract, the question arises whether civil law (in this case the Civil Code) allows. As explained above that this surrogacy contract position in the Civil Code as treaties are not named or innominaat, then this contract arise in society through the "door" "the principle of freedom of contract" and "open system" the third book of the Civil Code. Although the principle of freedom of contract agreements are not named or innominaat is permissible but still there are limits that must not conflict with the law, the public interest, and decency.

Agreement that arise and grow in the community who are classified as not named this agreement in its implementation still apply the general provisions of the agreement contained in the Civil Code. Innominaat surrogacy agreement as an agreement is specifically no regulation, but if we think in a way argumentum per analogiam, then we can apply Article 1548 of the Civil Code, Article 1320 of the Civil Code, and Article 1338 of the Civil Code. Regarding the tenancy agreement under Article 1548 of the Civil Code, which reads:

"Rent hire is an agreement by which one party to bind himself to provide enjoyment of goods to another party for a certain time, with the payment of a price that is affordable by the latter".

Thus the surrogacy agreement (lease of the uterus) is an outgrowth of their tenancy agreement contained in the Civil Law.

As the terms of the agreement in general, then the surrogacy agreement also must qualify the validity of the agreement under Article 1320 of the Civil Code, there are four 
requirements validity of the agreement, namely:
a. The agreement of the parties,
b. Competence to take legal action
c. A certain thing
d. A cause that kosher

In the case of this surrogacy agreement the spouses (intended parents) have agreed to bind himself as the tenant and the surrogacy (surrogate mother) uterus owners agreed to bind himself as the lessor. If both sides have agreed, then the surrogacy agreement (lease of the uterus) is valid under the terms of subjective elements.

The second condition is the skills of the parties to the contract, meaning that both sides should be the person who by law is stated as the subject of law and not including the category of people who are not competent to act legally under Article 1330 of the Civil Code that the person must be 21 years of age, not under guardianship. The provisions in the Civil Code are general, while specific to surrogacy agreement, in addition to being met proficiency by age, for surrogacy (surrogate mother) must be fulfilled in psychology, had a strong and healthy womb. As for the parents buyer (intended parents) should qualify as the owner of the egg and sperm is tied up in a legal marriage.
The third requirement regarding a particular case, it is intended that the agreement should have a certain object in the form of objects or the species and quantity of goods can be determined. If we apply this in the surrogacy agreement, then that becomes the object of the agreement in the form of planted seeds to the womb of a surrogate mother to have a child. Thus the object of the agreement consists of $^{8}$ : The obligation to accept an embryo surrogate mother, pregnant, keep the fetus, childbirth and handed the child to the parent customer.

The fourth requirement is a cause that is lawful, it is intended that the achievements in the agreement that gave birth to the engagement must be implemented or complied with by the parties, the absence of the specified performance, such agreement is not possible and will never exist between the parties. (Article 1320 jo. Article 1337 of the Civil Code). In other words, the reason that kosher is meant none other than the contents of the agreement. For the lawful limits set out in Article 1337 of the Civil Code, which reads "that any reason is prohibited where prohibited by law, or if contrary to morality or public order". 
If we apply this provision in the surrogacy agreement, the surrogacy agreement is not valid, because there are laws prohibiting it, namely Act No. 36 Of 2009 on Health.

In Article 127 of Act No. 36 of 2009 states that:

1) Efforts pregnancy outside the natural way can only be done by married couples valid with the following provisions:

a. The result of fertilization of the ovum and sperm of husband and wife is concerned implanted in the wife's womb from which the ovum comes.

b. Performed by health workers who have the expertise and authority to do so; and

c. In certain health care facilities.

2) The provisions concerning the terms of pregnancy outside the natural way as described in subsection (1) shall be regulated by Government Regulation.

It is thus clear that subsection (1) letter a expressly states that the result of fertilization of sperm and ovum of marital implanted in the uterus of the wife who has the ovum and not to the womb of another woman (the surrogate mother). Article 127 of Act No. 36 of 2009 as positive law in Indonesia only regulates IVF, does not regulate the validity of the lease execution of the uterus. Positive law regulating surrogacy contract specifically in Indonesia yet, but when using the argumentum per analigiam way of thinking, it can be applied to Article 1548, Article 1320 and Article 1338 of the Civil Code. Opinion of Purwoto S. Gandasubrata ${ }^{9}$ that: "The agreement is not valid surrogate mothers because it does not qualify the validity of the agreement, namely the requirement" for kosher "(geoorloofde oorzaak) pursuant to Article 1320 of the Civil Code) can also cause blurring of the child's legal status and equal illegitimate child"

Based on the above, the resulting child through IVF using a surrogate mother (the surrogate mother), based on Article 1320, Article 1548 of the Civil Code in Indonesia null and void, because contrary to the Health Act, the Marriage Law and the Law Islam (positive law in Indonesia).

\section{The legal status of surrogacy} agreements as th Innominaat Agreement in Islamic Law Perspective.

Efforts are underway couples who can not have children by natural way is by IVF. IVF is permissible (ja'iz) by syara'(Islamic rule), because it is an attempt to

9 Purwoto S. Gondosubroto, 1989, Perkembangan Teknologi Reproduksi Baru dan Implikasi Hukumnya, Makalah Seminar, SWI, Jakarta, p. 6 
realize one of the goals that gave birth to offspring marriage and many children. This is as hadith which reads:

"Marry you with a loving and fertile women (give birth child), for behold, I will be proud in front of the prophet with a number of you on the Day of Judgment". (HR. Ahmad).

Thus, if a treatment efforts to commercialize conception and give birth naturally has been done and it did not work, then it is possible to exploit the fertilization outside where natural (wife's womb). Egg fertilized by the husband's sperm cells are returned into place naturally in the womb of the wife in order to conceive naturally. The process is allowed in Islam, for what it is sunnah realize that the birth and many children. ${ }^{10}$

Observing the above provision, IVF is acceptable in Islam is fertilization of eggs by sperm in a tube vetri for some time after it was transferred to the womb of the wife. The egg and the sperm comes from the husband and wife are legitimate and included in the wife's womb. It is stipulated in Article 99 letter b Compilation of Islamic Law, which reads: "Children are legitimate is the handiwork of husband and wife who illegally outside the womb and be born by the wife".

While in the lease agreement of the uterus, the egg and sperm of couples who legitimately inserted into the uterus of other woman (the surrogate mother) Thus lease contract the uterus in Islam is not allowed, there are many Ulama assume that is haram (forbidden in Islam). If the result of fertilization of the sperm and egg of the couple who legitimately implanted/inserted into the mother's womb rental will arise the question of how the law incorporate the seeds into the mother's womb rental, while there are traditions of the Prophet that prohibits someone sprinkles or insert semen (sperm) into another woman's uterus (mother rented). ${ }^{11}$

In the Qur'an and Hadith no arrangement about the lease of the uterus, as well as in the books of jurisprudence no lease arrangement womb, so a surrogate mother (surrogate mother, the lease of the uterus) is a new problem arising as a result of the development of science and technology in the world medical. Thus the position of the uterus lease agreement includes an agreement innominaat and kelegalannya still many pros and cons. There are many intellectual Muslim are pros and cons are: ${ }^{12}$

11 Nabi said: "It is not lawful for a man who believes in Allah and the Last Day to a water hose lading others". A similar Hadith is: "There is no greater sin after shirk than the person who has placed his sperm in the uterus of a woman who is not lawful for him". Akhmad Fugaha, 2005, Solusi Problematika Aktual Hukum Islam (Keputusan Muktamar, Munas, Konbes Nahdlatul Ulama (1926-1999), Lajnah Ta'lif Wan Nasyr (LTNONU and Diantama, Edition. 2, Surabaya.

12 Umar Shihab, 1996, Hukum Islam dan Transformasi Pemikiran, Dina Utama, Semarang, p. 141 
Ali Akbar stated that "entrusts IVF in women who are not mothers should not, because the mother is impregnate because her womb disorder, while nursing their child to another woman with were hired permissible in Islam, then so-so also give reward to the woman who lends her womb" While the opinion At Syaikh'Ali AsyThantawi states that IVF using surrogate women can not be justified, because the woman's uterus containing had a hand in the formation and growth of the fetus from the mother's blood foods. ${ }^{13}$

Dr. Yusuf Qaradawi wrote that all the jurisprudent not allow surrogacy in various forms. If the sperm came from another man well known or not, then this is forbidden. Likewise, if the egg came from another woman, or the wife's egg cells, but another woman's womb, even this is not allowed. Why is that? because in this way will raise the question "who is the baby's mother, is the owner of eggs that carry the characteristics of offspring, or in women who suffer and endure pain due to pregnancy and childbirth?"14 Experts disagree jurisprudence in addressing these problems, there are some argue that the baby's mother is the owner of the egg, there is also the opinion of the
13 Muhammad Daruddin, 1997, Reproduksi Bayi Tabung Ditinjau dari Hukum Kedokteran, Hukum Perdata, Hukum Islam, Kalm Mulia, Jakarta, p. 132.

14 Yusuf Qaradhawi, 2001, Fatwa-Fatwa Kontemporer, Vol. 3, Gema Insani Pers, Jakarta, p. 660. baby's mother is the women who are pregnant and giving birth. The latter is especially appropriate physical meanings of the word of Allah SWT: "....... their mother nothing but the woman who gave birth to them ...............". (Surah Al-Mujaadilah: 2).

The result of ijtihad (Fatwa council Mujamma 'Islamic Fiqh) forbids the use of IVF techniques using sperm and ovum of a married couple and then the embryo is implanted into the uterus of another woman. ${ }^{15}$ Similarly, if the process is unlawful in artificial fertilization occurs between the husband's sperm cell with another woman's egg and the embryo is inserted into the wife's womb. Similarly unlawful if the process of artificial fertilization occurs between the sperm of another man (not her husband) with the egg wife, and diembrio placed in a wife's womb. ${ }^{16}$ MUI Fatwa No. Kep952/MUI/XI/1990 on artificial insemination/IVF, stated that: "Artificial Insiminasi/IVF with sperm and ova are taken muhtaram of couples husband and wife for other wives haraam/ not justified in Islam ". Thus it is clear that the IVF program by way of a surrogate mother in Islam is forbidden, because in the future will pose a problem of how the nature of a mother, how the legal relationship
15 Husni Thamrin, op.cit., P 96.

16 Kusdinard, Surrogate Mother dalam Pandangan http://www.kusdinard.id/2015/04/ Surrogate-mother-dalam-pandanganislam,html, Accessed on Pebruary 2018 
between parents buyer (owner seed) with children born by a surrogate mother, also will result in the determination the legal status of the child to whom the child was descent (followed by the descendants of their family).

3. The legal status of surrogacy agreements as the Innominaat Agreement the National Legal Perspective.

Civil Code still applies in Indonesia under Article II of the Transitional Provisions of the Constitution of 1945, thus the treaty provisions are generally used the provisions of the Civil Code. Thus any law made public transportation is now general agreement based on the provisions in the Civil Code. Likewise, if we examine surrogacy agreement that no special arrangements within the meaning of the Civil Code does not include an agreement named (nominaat), then the position of surrogacy agreement is included in the agreement were not named (innominaat).

Surrogacy agreements that arise and are likely to develop in this society is the growth of their IVF (in vitro fertilization). IVF program provided for in Article 127 subsection (1) letter a of Act No. 36 of 2009 on Health, which reads: "The results from the fertilization of sperm and ovum couple concerned implanted in the wife's womb from which the ovum comes" It is apparent from the phrase "..... implanted in the wife's womb" so a surrogate mother (mom substitute) normatively there is no regulation in Indonesia.

The practice of surrogacy agreements are prohibited in Indonesia, it is contained in the regulation of IVF Article 127 of Law 36 of 2009 on Health and Health Ministerial Decree No. 73/Menkes/Per/II/1999 about the Implementation of Reproductive Technology Artificial and Conditions terms validity of the agreement Article 1320 of the Civil Code is a cause that is kosher, is associated with the Article 1337 of the Civil Code and the principle of freedom of contract should not be contrary to law, order, and decency. More specifically in the Code of Service at Hospital IVF numbers into 4 states: "prohibited from engaging in any form of surrogacy"17, This guide is intended as a follow-up of the Minister of Health Decree No. 73/Menkes/Per/II/1999.

4. Law arising as a result of the surrogacy agreement by the Perspective of Civil Law, Islamic Law and National Law

a. Law arising as a result of the surrogacy agreement according to the Civil Law Perspective

The position of the lease agreement of the uterus (surrogacy) when viewed from the validity of the agreement under Article 1320 of the Civil Code concerning "a cause that kosher", linked to Article 1337
17 Pedoman Pelayanan Bayi Tabung di Rumah Sakit of Special Hospital and the private sector, the Directorate General of Medical Services, Ministry of Health of the Republic of Indonesia, 2000. 
of the Civil Code and the principle of freedom of contract, is null and void, since there is only legislation that allows programs IVF sperm and ova were derived from the husband and wife and the embryos implanted into the womb of his wife, not implanted into the uterus of surrogate mothers/mother rented. So legally uterus rental agreement never existed in Indonesia, but when it happens (remember the surrogacy agreement is the emergence in society), then there will be the question of how the status of the child, the right heir, and the rights of others.

No positive law only regulates the legal status of children, which is a legitimate child or children outside of mating set out in the Civil Code and Act No. 1 of 1974 on Marriage and the Compilation of Islamic Law. When this was questioned in a child of the IVF program as a result of the lease agreement uterus is whether his status as a legitimate child or children outside of marriage. To answer that should be known beforehand limits legitimate children and children outside of marriage.

Article 250 of the Civil Code regulating the definition legitimate child is: "a child born or brought up during the marriage, the husband obtained as a father". While Article 42 of Act No. 1 of 1974 states that "the child is the legitimate child born in or as a result of a legal marriage" Observing these two Articles, implied that a legitimate child is the result of natural copulation relationship of husband and wife tied valid marriage. Thus the key words of understanding legitimate child is the birth of the child the result of intercourse between husband and wife who are born by a wife within the bonds of marriage are legitimate. If the legitimate child's limits applied within the limits of the child of the IVF program through a surrogate mother, then children born to a surrogate mother's status as a legitimate child of the surrogate mother to the surrogate mother condition tied valid marriage husband and wife agree on rental uterus. However, if the surrogate mother's husband was denied, then pursuant to Article 251, Article 252, Article 253 of the Civil Code and Article 44 of Act No. 1 of 1974 interested parties can bring to trial on the legitimacy / absence of the child.

According

Desriza

Ratman, children born from the womb can rent status as a child outside of marriage is not recognized, if the status of his surrogate woman is a girl or a 
widow. In this case the child is born is "a child outside of marriage is not recognized", ie children born as adultery. ${ }^{18}$ In an agreement has been set of rights and obligations, as well as agreement surrogacy has given the rights and obligations of the parties including the obligation surrogate mother to hand over the baby who has been born, and obligations of husband and wife (parents) the buyer to provide a sum of money as agreed, Delivery of the baby is done legally by way of adoption. Thus the legal status of the child is a foster child.

Legally the child is a child with a surrogate mother of her husband, while the child is genetically the child married couples buyer. Efforts made in the surrogate mother is through the removal of children by the genetic parents, and if the child is treated as an adopted child, then she has the same rights and obligations with biological children. ${ }^{19}$

The legal consequences of their surrogacy agreement the other is the heir. The question is the result of IVF children via a surrogate mother will inherit the parents subscriber or a surrogate

18 Desriza Ratman, 2012, Surrogate Mother dalam Perspektif Etika dan Hukum : Bolehkan Sewa Rahim di Indonesia?, Elex Media Komputindo, Jakarta, p. 120.

19 Husni Thamrin, Op. Cit., P 72. mother. To determine the child heir to whom, should be the legal status of the child. The above has been described that the status of child of IVF through surrogacy agreements become legitimate child of the surrogate mother who tied rope legitimate marriage with her husband, so legally the child was heir to a surrogate mother. However, as this occurs because of the lease agreement the uterus, according to the agreement this child should be handed over to the parents buyer in a juridical way is by adoption, because the obligation is only a surrogate mother pregnant and give birth.

b. Law arising as a result of the surrogacy agreement according to Islamic Law Perspective

Position surrogacy agreement in any form is not allowed according to Islamic law. If the deal happens will lead to legal consequences on the child's status, mixing and removal descent and inheritance rights, and the rights of others. In other words, the work done by married couples who can not descent to the natural processes that perform IVF with uterine lease this way more mudharatnya. Although the teachings of Islamic Shariah teaches to not despair and taught for trying, but 
trying that according to the Law.

IVF is allowed according to the MUI fatwa is IVF sperm and ova derived from the husband and wife who tied rope legitimate marriage and the embryos implanted into her uterus. IVF is a result of technological developments in the field of medicine, so the wife who experience interruptions with reproductive organs can be treated with IVF. But the development of the IVF program is what is known as the surrogate mother or the surrogate mother, by an agreement between the husband and wife owners of the seed (sperm and ovum) by a surrogate mother who provides her womb to be put embryos from fertilized sperm and ovum husband and wife the buyer, with a reward. The task of the surrogate mother is only conceive and give birth.

MUI Fatwa Commission Decision in Indonesia II of 2006 on Masa'il Waqityyah Mu'ashirah, one decision to discuss the legal provisions surrogate uterus to embryo transfer, namely: ${ }^{20}$

a) Artificial insemination embryo transfer results between the husband's sperm and ovum wife placed into the uterus of another woman ruling may not (haram)

20 Decision of the Commission B Ijtima' Ulama, Indonesia Ulama Council Fatwa Committee. b) Artificial insemination embryo transfer results between the husband's sperm and ovum wife were placed on another legal wife's womb not (haram)

c) Artificial insemination embryo transfer results between the husband's sperm and ovum wife placed in the uterus of another woman who caused the husband and/or wife does not want the pregnancy is haraam.

d) Status of children born out of proceeds of money prohibited at point $a, b, c$ above are child laqith

According to the language, al-Laqith also known as al-manbuz, that a child who left his parents in the street. ${ }^{21}$ According to Sayyid Sabiq is meant by al-laqith (child findings) is a small child who has not baliq, which is found on the street, or astray on the road and no known family. ${ }^{22}$ In Islam to children who have not baliqh found on the street, not knowing who her parents, then categorized as laqith, as well as children born from embryo transfer to the uterus implementation surrogate children also called laqith. Against this laqith child for
21 Ahmad Kamil dan M. Fauzan, 2008, Hukum Perlindungan dan Pengangkatan Anak di Indonesia, P.T.Raja Grafindo Persada, Jakarta, p. 164

22 Sayyid Sabiq, 1994, Fiqhus Sunah, terjemahan Moh. Thalib, P.T. Al-Maarif, Bandung, p. 82 
parents buyer in order to have a relationship with the child descent is by way recognize the child, and to acknowledge his son laqith become, through the adoption procedure. This does not mean that Islam allows people to care Janim because such actions are already defined as unlawful acts.

According to the MUI Fatwa Decision Ijtihad Commission B astral conjunction 'Ulama of 2006 stating that children born from embryo transfer to the uterus surrogate mothers are children laqith or child findings, the child was born out of the act custody of fetuses in the womb of a surrogate mother only has a relationship of inheritance heir with mother originated. That is because children born care act fetus in the uterus of surrogate mothers only have descent relationship with the birth mother. If the child laqith died leaving an estate, and had no heirs, the heirs will be owned property treasury. ${ }^{23}$ Basically the womb rental practices, status of children born through the womb lease there are pros and counterproductive, so if there is a dispute in connection with

23 Fadly, Bab Laqith ( Bayi/Anak Kecil yang Ditemukan)

http://alislamu.com/index.php?option=com.co ntent\&task=vie\&id=286\&ltemid-22. Accessed on February 2018 surrogacy agreement (lease uterus) is, the pengadilanlah decided.

c. Law arising as a result of the surrogacy agreement according to the National Legal Perspective

In Indonesia on the practice of pregnancy outside the natural way stipulated in Act No. 36 Of 2009 on Health and Health Ministerial Decree No. 73/Menkes/ Per/II/1999, which clearly only menyatur about IVF sperm cells fertilized ovum husband and wife who are bound in rope legitimate marriage and embryo inserted into the uterus of his wife. From these provisions, it is clear that there is no lease agreement womb settings in Indonesia. When examined from another positive law in force in Indonesia, namely the Civil Code and the Law of Islam, the position is not valid surrogacy agreement, although there are pros and cons. The surrogacy agreement will lead to the legal consequences of the status of the child, heir rights and the rights of others.

\section{Closing}

\section{Conclusion}

a. Legal Position And Due To Legal Surrogacy Agreement As An Innominaat Agreement In The Perspective Of Civil Law, Islamic Law And National Law 
Legal standing a innominaat agreement in the perspective of civil law, in particular there is no regulation, but if we think in a way argumentum per analogiam, then we can apply Article 1548 of the Civil Code, Article 1320 of the Civil Code, and Article 1338 of the Civil Code. The practice of surrogacy agreement is only based on the law of treaties, as subject to the provisions of the Civil Code. Thus the position of agreement surrogacy as an agreement innominaat and children produced through IVF using a surrogate mother (the surrogate mother), based on Article 1320, Article 1548 of the Civil Code in Indonesia null and void, because contrary to the Health Act, Act OF Marriage and Islamic law (positive law in Indonesia).

The position of surrogacy agreements as innominaat agreement in the perspective of Islamic law is not permitted or forbidden convicted. IVF is acceptable in Islam is fertilization of eggs by sperm in a tube vetri coming from a couple who tied a valid marriage, and embryonic included in the wife's womb.

The position of surrogacy agreements as treaties innominaat in national legal perspective that surrogacy agreements no special arrangements within the meaning of the Civil Code does not include an agreement named (nominaat), Then the position of surrogacy agreement is included in the agreement were not named (innominaat) and menurut Pedoman Services Hospital IVF numbers into 4 states: "prohibited from engaging in any form of surrogacy"24, This guide is intended as a followup of the Minister of Health Decree No.73/ Menkes/ Pe /II/ 1999.

b. Law arising as a result of the surrogacy agreement by the Perspective of Civil Law, Islamic Law and National Law

Legal $\begin{array}{r}\text { consequences } \\ \text { surrogacy }\end{array}$
arising in civil law
agreements under collats
perspective is related to the
legal status of children,
inheritance and other rights.
The legal status of children
born to a surrogate mother's
status as a legitimate child of
the surrogate mother to the
surrogate mother condition
tied valid marriage husband
and wife agree on rental
uterus. However, children born
from the womb can rent status
as a child outside of marriage
is not recognized, if the status
of his surrogate woman is a
girl or a widow. Thus legally

24 Pedoman Pelayanan Bayi Tabung di Rumah Sakit of Special Hospital and the private sector, the Directorate General of Medical Services, Ministry of Health of the Republic of Indonesia, 2000. 
the child is a child with a surrogate mother of her husband, while the child is genetically the child married couples buyer. Efforts made in the surrogate mother is through adoption, so that the status of the child as a foster child from parental genes. While inheritance rights depends on the legal status of the child, if he existed as a legitimate child then the child as the heir of his parents, but if the child's status as a child outside of mating the children only have a relationship of civil with her mother and her mother's family, if the child this status as an adopted child of her genetic mother then replace the position adopted child's biological child so he is entitled to the inheritance of genetic parents. This provision is not much different from the legal consequences under national law. if the child's status as an adopted child of her genetic mother then replace the position adopted child's biological child so he is entitled to the inheritance of genetic parents. This provision is not much different from the legal consequences under national law. if the child's status as an adopted child of her genetic mother then replace the position adopted child's biological child so he is entitled to the inheritance of genetic parents. This provision is not much different from the legal consequences under national law.

As a result of surrogacy contract law as a covenant innominaat perspective of Islamic law relating to the legal status of children, descent, inheritance rights, and the rights of others. The legal status of children of IVF by way of lease of the uterus is called the child laqith. Against this laqith child for parents buyer in order to have a relationship with the child descent is by way recognize the child, and to acknowledge his son laqith become, through the adoption procedure. Children born care act fetus in the uterus of surrogate mothers have only heir inheritance relationship with the birth mother. That is because children born care act fetus in the uterus of surrogate mothers only have a relationship with the mother who gave birth descent

\section{c. Suggestion}

The surrogacy agreement is berkembangan of IVF is likely to be secretly performed by couples who want to have children yet to experience problems in the reproductive organs. Agreement surrogacy in particular there is no regulation, for it to legislators (Parliament and Government) should consider carefully because considering that Indonesia has a five religions recognized by the state as well 
as the enactment of four legal system has its own characteristics enactment in the community.

In addition the government and Parliament must also consider wastefulness arising from this womb lease agreement, because in the future there will be problems regarding specifies the legal status of children, descent, inheritance rights and the rights of others.

\section{Book}

\section{BIBLIOGRAPHY}

Qur'an and Hadith.

Ahmad Kamil dan M. Fauzan, 2008, Hukum Perlindungan dan Pengangkatan Anak di Indonesia, P.T.Raja Grafindo Persada, Jakarta.

Akhmad Fugaha, 2005, Solusi Problematika Aktual Hukum Islam (Keputusan Muktamar, Munas, Konbes Nahdlatul Ulama (1926-1999), Lajnah Ta'lif Wan Nasyr (LTN) NU and Diantama, Edition. 2, Surabaya.

Desriza Ratman, 2012, Surrogate Mother dalam Perspektif Etika dan Hukum : Bolehkan Sewa Rahim di Indonesia ?, Elex Media Komputindo.

Husni Thamrin, 2014, Aspek Hukum Bayi Tabung dan Sewa Rahim, Prespektif Hukum Perdata dan Hukum Islam, Aswaja Pressindo, Yogyakarta.

Hilman Hadikusuma, 1990, Hukum Perkawinan Indonesia menurut Perundangan, Hukum Adat, Hukum Agama, Mandar Maju

K. Wantjik Saleh, 1976, Hukum Perkawinan Indonesia, Edition IV, Galia Indonesia, Jakarta

Mukti Fajar dan Yulianto Ahmad, 2007, Dualisme Penelitian Hukum, Pensil Komunika, Yogyakarta.

Muhammad Daruddin, 1997, Reproduksi Bayi Tabung Ditinjau dari Hukum Kedokteran, Hukum Perdata, Hukum Islam, Kalm Mulia, Jakarta.

Purwoto S. Gondosubroto, 1989, Perkembangan Teknologi Reproduksi Baru dan Implikasi Hukumnya, Makalah Seminar , SWI, Jakarta

Salim dan Erlies Septiana N, 2014, Perkembangan Hukum Kontrak Innomenaat di Indonesia, Edition II, Sinar Grafika, Jakarta.

Sony Dewi Judiasih, 2016, Aspek Hukum Sewa Rahim dalam Perspektif Hukum Indonesia,

P.T. Refika Aditama, Bandung.

Sayyid Sabiq, 1994, Fiqhus Sunah, terjemahan Moh. Thalib, P.T. Al-Maarif, Bandung. Umar Shihab, 1996, Hukum Islam dan Transformasi Pemikiran, Dina Utama, Semarang. Yusuf Qaradhawi, 2001, Fatwa-Fatwa Kontemporer Vol. 3, Gema Insani Pers, Jakarta

\section{Legislation and others}

Act No. 1 of 1974 about Marriage.

Act No. 36 Of 2009 about Health. 
The Book of the Law of Civil Law (Civil Code).

Compilation of Islamic Law (KHI).

Minister of Health Decree No.73/Menkes/Per/II/1999.

Decision of the Commission B astral conjunction 'Ulama, Indonesia Ulama Council Fatwa Committee.

Pedoman Pelayanan Bayi Tabung di Rumah Sakit of Special Hospital and the private sector, the Directorate General of Medical Services, Ministry of Health of the Republic of Indonesia, 2000.

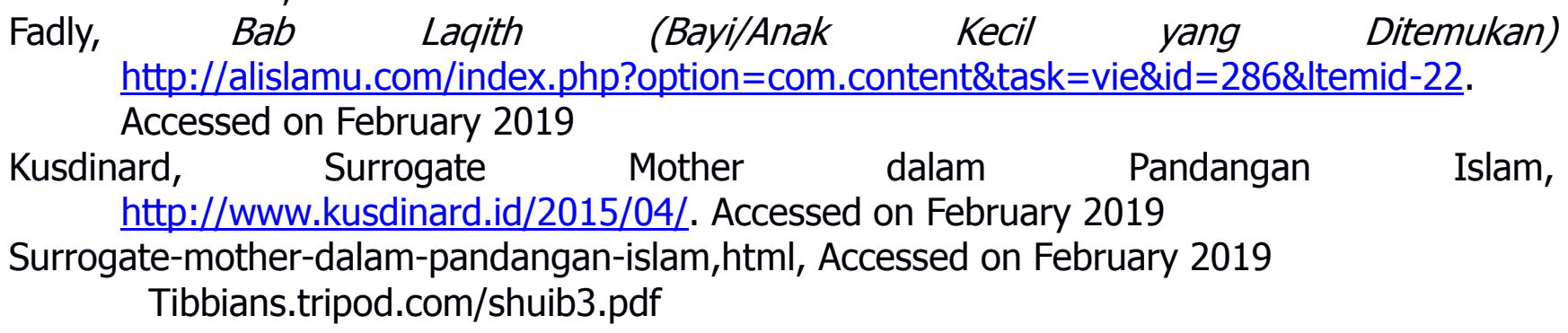

